\title{
Ślady Komeńskiego we współczesności: utopijność versus realna obecność jego założeń pedagogicznych i społecznych
}

\author{
Traces of Comenius in the contemporary: utopian or real presence \\ of his pedagogical and social assumptions
}

DOI: $10.34739 /$ szk.2021.08.04

\begin{abstract}
Streszczenie: Artykuł jest próbą analizy wybranych aspektów poglądów pedagogicznych i społecznych Jana Amosa Komeńskiego. Odniesienie idei Komeńskiego do współczesności jest poszukiwaniem w niej jego śladów. Jednocześnie w literaturze obejmującej studia nad dorobkiem Komeńskiego spotyka się kategorie utopii i realizmu. Dla ich wyjaśnienia podjęto się krótkiej analizy relacji między utopią a pedagogiką. W pedagogice jako nauce społecznej zawsze kreuje się wizję lepszego świata, co nie zawsze znajduje akceptację. Poglądy Komeńskiego, określane jako utopia, dzisiaj wydają się urzeczywistniane w praktyce i teorii pedagogicznej, chociaż nie zawsze sięga się do ich faktycznych źródeł.
\end{abstract}

Słowa kluczowe: Komeński, utopia, realizm, pedagogika, założenia społeczne

\begin{abstract}
The article is an attempt to analyze selected aspects in the pedagogical and social views of John Amos Comenius. Comparing Comenius with the present day is looking for his traces in it. At the same time, in the literature covering studies of Comenius' output, there are categories of utopia and realism. To explain them, a short analysis of the relationship between utopia and pedagogy was undertaken. In pedagogy as a social science, a vision of a better world is always created, which is not always accepted. Comenius' views, described as utopia, seem to be accomplished today in practice and pedagogical theory, although their actual sources are not always used.
\end{abstract}

Keywords: Comenius, utopia, realism, pedagogy, social assumptions

\section{Wprowadzenie}

Artykuł obejmuje wybrane założenia pedagogiczne i społeczne J.A. Komeńskiego i jest ich zderzeniem z obecną rzeczywistością, określeniem stopnia ich realności, jak i utopijności. Refleksja nad nimi poprzedzona została źródłową analizą literatury przedmiotu $\mathrm{w}$ zakresie utopii i jej związków 
z pedagogiką. Nie stanowi ona wyczerpującego obrazu, jest jedynie jego wąskim zarysem.

Wydaje się, że już z założenia - porównywanie Komeńskiego w jego twórczości i poglądach będących zestawieniem idei różnych epok, kontekstów społeczno-kulturowych i politycznych - staje się komparatystyczną trudnością, wynikającą ze swej historycznej różnorodności. Żywotność jego idei potwierdza jednak ich nośność, niezależnie, czy są odbierane jako pedagogiczno-społeczny uniwersalizm, czy też uznawane za kontrowersyjne lub archaiczne.

Jeden z czołowych badaczy Komeńskiego w pedagogice określa obszar badawczy komeniologii, który możemy „rozpatrywać także przestrzennie, temporalnie, personalnie, komparatystycznie oraz jako metarefleksję powiązaną z badaniami recepcyjnymi" (Sztobryn: 2019: 29). Wydaje się, że transdyscyplinarny charakter komeniologii i pluralizm w recepcji poglądów Komeńskiego, inne perspektywy rozumienia i pragmatyzmu, dopuszczają różne wykładnie jego dorobku. Nam, osobom żyjącym tu i teraz, mówienie o śladach Komeńskiego we współczesności jest naszą subiektywną wizją, która przeniesiona przy użyciu wehikułu czasu mogłaby rozmijać się w swych założeniach, postrzeganiu społecznym i stopniu użyteczności pewnych rozwiązań z ówczesnymi warunkami społeczno-politycznymi i kulturowymi. Mówienie o jego społecznym i pedagogicznym programie, niezależnie od przyjętej perspektywy dyscyplinarnej, jest w każdym przypadku li tylko naszą współczesną interpretacją założeń, rozważań czy teorii, chociażby pansoficznej koncepcji wychowania człowieka u Komeńskiego polegającej „na dostosowaniu człowieka do życia w świecie dla niego zrozumiałym. Miał nadzieję na pełne zrozumienie świata, to jest przyrody, człowieka i Boga" (Bieńkowski, 1998: 89). Szczytne to założenie, lecz jego kontekst wydaje się niezwykle złożony i „uwikłany” w realia danego czasu czy epoki, co dzisiaj w przypadku eksploatacji przyrody, ekspansji człowieka na każdym polu jego egzystencji, liberalizmu i zmian aksjologicznych, często przedmiotowej, a nie podmiotowej wartości człowieka i kulturowego neomarksizmu mija się z humanistyczną wizją Komeńskiego. Współczesny ład aksjonormatywny wyznaczają inne realia społeczne, co utrudnia porównywanie typowych dla czasów Komeńskiego wartości, wagi problemów, ich społecznej hierarchii. Być może Komeński dzisiaj, w czasach nam współczesnych, odrzuciłby naszą wizję człowieka i świata lub też naszą interpretację jego myśli. Tymczasem B. Suchodolski uznał, że „społeczny i pedagogiczny program Komeńskiego miał cechy utopijne. Ale to, co w nim było nowoczesne - a także i nam współczesne - to była wiara w możliwość urzeczywistniania utopii" (1979: 53). Wspomniany 
Suchodolski pisał te słowa ponad czterdzieści lat temu, w epoce komunizmu, dyktującej inną koncepcję człowieka, którego wolność duchowa czy intelektualna stała pod znakiem zapytania. Tymczasem „Komeński przeciwstawia się negatywnym zjawiskom społecznym, tworząc w swojej pansofii miejsce dla ich dosłownej antynomii: równości, upowszechnienia edukacji, zdolności tworzenia, przeobrażania i uszczęśliwiania siebie i świata oraz życia w harmonii z Bogiem" (Dobrowolska, 2020: 126). Czy założenie o utopijności koncepcji Komeńskiego u Suchodolskiego jest w całej swej strukturze istotnie prawdziwe? Wspomniana wolność i „naprawa człowieka” ma według Suchodolskiego zupełnie inne zabarwienie i wymowę, zwłaszcza w stwierdzeniu: „gdy strategia Komeńskiego, wedle której powszechne i pansoficzne wychowanie prowadzić miało do naprawy świata, zawiodła, strategia Marksa - tamtej przeciwstawna - osiągnęła zwycięstwo" (Suchodolski, 1979: 58). Prawdopodobnie chodziło tu Suchodolskiemu o ideę równości i sprawiedliwości społecznej, będącej hasłami ustroju komunistycznego.

O innej „naprawie świata” myślał Komeński, o „innej” zaś Suchodolski, włączając „nowego" człowieka w marksistowskie założenia i idee, stanowiące w latach siedemdziesiątych „podstawy nowoczesnej pedagogiki”, w której „program naprawy człowieka zyskał nowe warunki, nowe perspektywy i nowe możliwości" (Suchodolski, 1979: 58). Czy sam w sobie marksizm nie stanowił także formy utopii zawierającej pożądany obraz rzeczywistości społecznej i realizowany w ideologicznym nakazie? Żywa wówczas obecność Komeńskiego w pedagogice okresu przed transformacją ustrojową nie jest w moim przekonaniu utopią z dzisiejszego punktu widzenia, lecz interpretacją pewnych haseł i założeń mieszczących się w ówczesnej ideologii. „Wciąż jeszcze wielu pedagogów żyje gorzkimi wspomnieniami marksistowskoleninowskiej utopii ładu społecznego, gdy wychowanie naginano do obowiązującej ideologii, tymczasem scena polityczna i kulturowa obróciły się niemal o sto osiemdziesiąt stopni i - co jest paradoksalne - często ci sami wychowawcy i nauczyciele nie akceptują przeobrażeń zachodzących w szkolnictwie, tym razem naginanym dzisiaj do reguł rządzących wolnym rynkiem" (Dróżdż, 2000: 5). Pedagogiczny i społeczny program Komeńskiego jest tak uniwersalny i ponadczasowy, że wymyka się ideologiom, traktującym człowieka jako posłuszne narzędzie manipulacji, ograniczone do przyjęcia uznanych politycznie i społecznie standardów, pozbawiającym go sfery duchowej. „Bo przecież - jak pisze Komeński w Panegersii w rozdziale IV - dzięki temu, czym różnimy się od zwierząt, czym właśnie je przewyższamy, zbliżamy się do wzniosłości Boga" (za: Suchodolski, 1979: 77), którego wcześniej i dzisiaj niezależnie od wolności słowa, przekonań i religii - usuwa się z przestrzeni 
publicznej, zwłaszcza jeśli mówimy o postępującej ateizacji życia społecznego. Współczesna zmiana perspektywy kulturowej stawia edukację i stosunki społeczne w innym porządku. Kreuje z kolei utopię eudajmonistyczną, tworząc ułudę absolutnego szczęścia, które zapewnia globalnym społeczeństwom nieokiełznana konsumpcja i udział w ciągłej rozrywce. Cytowany już A. Dróżdż pisze: „kreatorzy eudajmonistycznej utopii, będącej czymś w rodzaju konsumenckiego raju, wykorzystujący potęgę mediów elektronicznych, z bylejakości czynią wzór do naśladowania, a nawet każdą jarmarczną niedorzeczność potrafią przetworzyć $\mathrm{w}$ naukową teorię, popartą empirycznymi dowodami. W świecie zamazanych wartości i wątpliwych autorytetów korzystanie z rozumu przestaje być warunkiem kulturowej adaptacji, co więcej może stać się czymś anachronicznym i wstydliwym" (Dróżdż, 2000: 5). U Komeńskiego również dopatrzeć się możemy elementów utopii eudajmonistycznej, w innej perspektywie, podyktowanej ówczesnymi warunkami społeczno-politycznymi. Pojawia się pytanie o to, co jest utopią w poglądach Komeńskiego, czy była ona utopią dla niego i jest także dla nas? Czy warunki, w jakich przychodzi nam żyć, zmieniają kategorię utopii i realizmu, stawiając je w przeciwstawnych perspektywach?

\section{Utopia w pedagogice - relacje między pedagogiką a utopią}

Rozważania należy rozpocząć od pojęcia utopii, mającego swe źródło w Utopii Thomasa Morusa (More'a), oznaczającego miejsce, którego nie ma, coś nierealnego, będącego w sferze marzeń i pożądania (More, 2001). Zważywszy na czas historyczny, Morus stworzył wizję idealnego państwa i systemu społecznego, odnosząc się do warunków ówczesnej szesnastowiecznej Anglii. Pierwsze wydanie opublikowano w 1516 roku, podczas gdy Komeński rodzi się w roku 1592. Warto zwrócić uwagę na utopistów XVI i XVII wieku w opracowaniu Waldemara Voise'a, w którym obok Morusa pojawia się także postać Andrzeja Frycza Modrzewskiego i jego traktat polityczny ( $O$ poprawie Rzeczypospolitej), będącego swoistą utopią (Voise, 1972).

Współcześnie w Encyklopedii PWN (https://encyklopedia.pwn) wydawca określa termin utopia, przyjmując cztery kategorie jego zastosowania: 1) w odniesieniu do wizji idealnego społeczeństwa, różniącego się od status quo, 2) jako projekt przebudowy społecznej odrzucającej obecne realia, 3) jako obrazy pożądanego stanu rzeczy, 4) odnosząc się do gatunku literatury, zwykle prozy przedstawiającej idealne życie jakiejś społeczności. Utopia Morusa nie jest pierwsza w nowożytnym świecie. Już w starożytności u Platona w jego Państwie powstały pierwsze zręby utopijnego ładu społecznego, $\mathrm{z}$ wizją idealnego świata. 
Zasadniczo utopia wydaje się czymś nieosiągalnym, trudnym do realizacji z punktu widzenia nowej wizji i roztaczania nierealnych horyzontów. Tworzona jest zwykle w czasie historycznym, w którym owe wizje kłócą się z zastanym status quo i wyrastają ponad wszelkie możliwe do realizacji plany, posunięcia, schematy. Ich koncepcje wydają się mentalnie i fizycznie niemożliwe w procesach społecznej przebudowy i implementacji, co zwykle kończy się ich odrzuceniem, czasem społeczną pogardą lub koniecznością ich dorastania do czasów, w których zostaną zaakceptowane. Tak dzieje się z historią wynalazków, tworzeniem koncepcji artystycznych, w tym np. z malarstwem, rzeźbą czy muzyką. Ich twórcy często w swoim rzeczywistym czasie tworzenia byli niedoceniani, a ich projekty wyrastały ponad obowiązujące kody kulturowe. Zjawisko to tłumaczy pogląd na twórczość autorstwa M. Csikszentmihalyi'ego, według którego twórczość jest konsekwencją zdarzeń i interakcji społecznych, w których znaczącą rolę odgrywają ludzie lub środowiska określani przez niego jako „portierzy” (za: Nęcka, 2001). Coś może być społecznie akceptowalne lub też nie, w zależności od obowiązujących w danym czasie społecznych kodów, symboli, zapotrzebowania, kryteriów oceny użyteczności itp. Czy zatem wytwór ludzki może być utopią, skoro uwikłany jest w społeczną tkankę, jej ocenę, przydatność społeczną i obowiązujący aksjologiczny charakter? Wytworami są przecież teorie, koncepcje, projekty, te zaś wszechobecnie występują w pedagogice. Ona sama i jej rozwój jako nauki teoretyczno-praktycznej opiera się na tworzeniu koncepcji, które w przyszłości są wdrażane w praktyce edukacyjnej lub uznawane za nieosiągalne. Nierzadko nowe teorie pedagogiczne nie znajdują swego potwierdzenia w pracy szkoły czy w systemach edukacyjnych. Zdaniem praktyków nie ma możliwości ich wdrożenia, wyrastają bowiem poza dopuszczalne i sprawdzone schematy i obowiązujące paradygmaty. Odrzucają nowe możliwości i rozwiązania, bo te zawsze budzą lęk przed nowym i nieznanym, stanowiąc tym samym pewien bufor i inhibitor zmiany.

„Istnieje wiele strukturalnych powiązań utopii i pedagogiki. Gdyby się pozbawiło pedagogikę pierwiastka utopijnego, wtedy każda jej teoria, każda systemowa koncepcja szkolnictwa straciłaby sens istnienia. Pedagogika znajduje dla siebie uzasadnienie w tym, co dopiero będzie, tzn. w efektach wychowawczych, które sprawdzą się po latach. Ale prawdziwa pedagogika, jak i całe szkolnictwo, muszą być wolne od utopii. Oto paradoks, z którym często nie umiemy sobie poradzić" (Dróżdż, 2000: 7). Wspomniany autor podkreśla znaczenie utopii w pedagogice jako stymulację do rozwoju i generowania nowych rozwiązań, które z założenia utopijne - w teoriach czy koncepcjach weryfikowalne są po latach i potwierdzają lub też nie sens i zasadność wcze- 
śniejszych projektów. Są one pierwotnie pewnym ideałem - jak zakłada autor - tworzącym utopijną przestrzeń edukacyjną. Jak pisze: „Należy pamiętać, że gdzie istnieje planowanie, tam jest tworzona bądź przywoływana jako niedościgły model przestrzeń utopijna $\mathrm{z}$ obecnym $\mathrm{w}$ niej ideałem. Tak więc pedagogika organizująca przestrzeń edukacyjną nigdy nie uwolni się od pierwiastka utopijnego" (Dróżdż, 2000: 7). Od wieków kształcenie i wychowanie poddawane było kreowaniu ideałów, wizji lepszego świata, co mieściło się w doktrynach politycznych i społecznych, nierzadko będąc opozycją do aktualnie obowiązujących systemów, wskazywaniem ich niedoskonałości lub wręcz szkodliwości.

B. Śliwerski w rozważaniach nad utopią stawia pytanie o jej sens i istotę. Pyta, co o niej decyduje i czy stanowi ją każda wizja, czy są jakieś jej charakterystyczne cechy (Śliwerski, 2017: 12). W przypadku utopii pedagogicznych w rozumieniu B. Śliwerskiego nie mogą mieć one charakteru programu politycznego czy ruchu społeczno-pedagogicznego, gdyż wymagałyby ich realizacji, podczas gdy wizja nie poddaje się modyfikacjom i musi być zachowana w swej pierwotnej, niezmiennej formie. Jak stwierdza przywołany autor: „Nie dysponujemy współcześnie żadną utopią edukacyjną. Nawet Korczakowska wizja świata Króla Maciusia Pierwszego spełniła się na świecie, istnieją bowiem już republiki dziecięce" (Śliwerski, 2017: 14). Jako pedagog uważa, że możemy mówić jedynie o niespełnionych utopiach edukacyjnych, „(...), które u swych podstaw były alternatywami mikroedukacyjnymi (wyspy oporu edukacyjnego, ruch klas autorskich w szkolnictwie publicznym, edukacja domowa jako utopia ucieczki), mezoedukacyjnymi (bon oświatowy w kilku gminach) czy makroedukacyjnymi (decentralizacja, decentracja i uspołecznienie szkolnictwa publicznego)" (Śliwerski, 2017: 14-15). Utopią są zatem utopie edukacyjne. Obejmują przeszłość, teraźniejszość i przyszłość, w której dokonać się może realizacja idei, planu, założenia. Coś, co określa się utopią z racji braku akceptacji i możliwości zastosowania, może doczekać się wdrożenia w przyszłości, czego z dzisiejszego punktu widzenia i płaszczyzny teraźniejszości nie dostrzegamy. Utopią jest zatem założenie, że coś jest nierealne, stanowi li tylko wizję, bo przecież empirycznie nie możemy określić i antycypować tego, co ona nam przyniesie. Jak konkluduje B. Śliwerski: „Nie widzę na horyzoncie polskiej pedagogiki szkolnej nowej utopii edukacyjnej poza tymi, które w żadnej mierze nie obligują władz do działania na rzecz ich wdrażania" (Śliwerski, 2017: 15), uznając jednocześnie wszelkie oddolne inicjatywy, zmiany czy reformy, których się nie wdraża. Idąc za konkluzją Karla Mannheima przyjmującą za utopijną orientację to, co „rozsadza istniejący w danym czasie porządek bytu”, B. Śliwerski nie dostrzega w obecnej 
sytuacji edukacyjnej żadnych znamion utopii edukacyjnej (Śliwerski, 2017: 15). Wszelkie nowe pomysły, idee - mimo ciągłych dyskusji społecznych na temat zmian edukacyjnych - są odrzucane lub torpedowane w imię prowadzonej polityki oświatowej. Jest to wynikiem nie tyle ich nierealnych założeń i przekroczonych granic realizacji, ile zwykłą ignorancją, politycznym i ekonomicznym rachunkiem lub instrumentalnym działaniem dla określonych celów. Kształt edukacji i jej wizje są walką o kształt pedagogiki, która wyznacza kierunki czy trendy wychowania i formowania jednostki. Mieliśmy pedagogikę socjalistyczną, mamy postmodernizm, a każde z nich kreśli inną wizję człowieka.

Michał Głażewski, przedstawiając pedagogiczne konteksty utopii, wskazuje na jej łączność z utopiami społecznymi. Te ostatnie zawsze odnoszą się do człowieka jako głównego podmiotu życia społecznego, a człowiek z całym arsenałem wiekowych, rozwojowych aspektów jest podmiotem nauk społecznych, do których należy pedagogika. Jak twierdzi wspomniany autor: „(...) utopie zajmują się człowiekiem abstrakcyjnym, wyidealizowanym, anonimowym i bezosobowym, a nie konkretnym, żyjącym tu i teraz (...)" (Głażewski, 2017: 36). Antropologiczny wymiar utopii społecznej czy pedagogicznej nie może stawiać człowieka w jego statycznej formie działań, zachowań, postaw, lecz przyjmuje strukturę dynamiczną, którą trudno jest przewidzieć, wcielić, zwłaszcza że jest ona zawsze uwikłana w społeczne i kulturowe konteksty. W swoich rozważaniach M. Głażewski zwraca uwagę na typologie utopii i jej właściwości. Określa je w kontekstach historycznych, nawiązując do kategorii przymusu, typowej dla komunizmu czy wcześniejszych totalitaryzmów, które również stanowiły swoistą utopię i wobec których współcześnie przyjmuje się pogardliwe i krytyczne stanowisko. Zdaniem Głażewskiego utopie są „naiwnym obrazem nowych społeczeństw”, choć z natury nie są naiwne i są propozycją ładu społecznego w całościowym jego ujęciu (2017: 40-41). Utopia sama w sobie „jest wyrazem metafizycznej tęsknoty człowieka za spełnieniem, za doskonałością, za pewnością prawdy, realną obecnością dobra i sprawiedliwości, za tymi aksjomatami świadomości ludzkiej, o których się intuicyjnie wie, że są lub mogą istnieć, nawet jeśli nie jesteśmy w stanie podać ich naukowej definicji” (Głażewski, 2017: 40). Wykluczanie z pedagogicznej refleksji i pedagogicznej praktyki wszelkich form utopijności może oznaczać w ocenie autora eliminację „z życia wartości absolutnych, metafizycznych źródeł prawd ostatecznych, czy choćby nadziei na istnienie takich prawd, a tym samym zubożenie i spłaszczenie świadomości człowieka wyłącznie do jednego wymiaru homo faber czy homo oeconomicus (...)" (Głażewski, 2017: 39). 
Wielość spojrzeń na utopię $\mathrm{w}$ jej relacjach z pedagogiką i wskazanie pedagogicznych kontekstów utopii wydaje się ciągłym dążeniem do osiągnięcia idealnego stanu wychowania, kształtowania człowieka, z jednoczesnym rozwojem wszystkich jego sfer, w tym duchowych. Uformowanie wspomnianego homo faber czy oeconomicus pozbawia go czysto ludzkich aspektów, czyniąc z niego narzędzie pracy, instrumentalny, uprzedmiotowiony byt, którego wartość mierzona jest nie tyle jego osobowymi i intelektualnymi przymiotami, ile wytworzonymi dobrami i „mocą przerobową”, „możliwością drenażu umysłu", ilością, a nie jakością. Nawiązując do Utopii More’a, dwie autorki, Barbara Chojnacka i Katarzyna Ciarcińska, uważają, że „opis życia Utopian świetnie wpisuje się w trendy i pragnienia współczesnych mieszkańców Zachodu: umęczeni trwającą od świtu do nocy pracą dla wielkich korporacji, pragną traktować zatrudnienie jako narzędzie do zapewnienia bytu i nic ponadto (...)" (2017: 99).

Współczesny świat, mimo haseł demokratyzacji życia społecznego, podkreślania praw człowieka, paradoksalnie feruje ich łamanie, odrzuca ludzką godność, a w wielu przypadkach prawo do głosu i samostanowienia. Czy ten świat i głoszone w przestrzeni publicznej hasła to też utopia, a tym samym polityczna poprawność dająca złudzenie powszechnej sprawiedliwości i szczęśliwości? Czy powszechnie głoszona idea „edukacji dla wszystkich”, „edukacji przez całe życie” jest istotnie realizowana i czy faktycznie daje wszystkim jednakowe szanse? Czy to też nie są utopie stanowiące o niezbywalnych dla człowieka prawach i możliwościach, a w rzeczywistości przekształcane przez systemowe i polityczne struktury? Z drugiej zaś strony patrząc, można stwierdzić, że często utopijne wizje - jak podkreślają wspomniane wyżej autorki - stają się rzeczywistością, tak jak szkoła w Summerhill czy korczakowska wizja samorządności i jej renesans w formie szkół społecznych, społecznych gremiów w edukacji i demokratyzacji oświaty, mimo wielu krytycznych komentarzy i ocen i ciągłej niedoskonałości systemu edukacji.

Granica między utopią a rzeczywistością nie jest jednoznaczna. W literaturze przedmiotu podkreśla się wiele związków między utopią a antyutopią (Chojnacka, Ciarcińska, 2017: 99-100), między utopią a wizją, gdzie oba pojęcia uznawane są za zniekształcenia poznawcze (Ferenz, 2017: 17). W przedmiotowych rozważaniach szczególnie ważne jest uchwycenie związku między utopią a pedagogiką, z racji refleksji nad Komeńskim i jego społeczno-pedagogicznymi założeniami. Trudno też dokonać jest gruntownej analizy pojęcia utopii i jej związków z rzeczywistością (w tym przypadku z realną rzeczywistością w pedagogice) z racji rozległej literatury dotyczącej różnych dyscyplin, w tym filozofii, literatury, historii. Jak konkluduje Stankomir Nicieja 
„Niejako z definicji utopia to gatunek wymykający się łatwemu zaszufladkowaniu, o wybitnie interdyscyplinarnym i wielowymiarowym charakterze. Wszak łączy ona w sobie zarówno właściwości dzieła czysto literackiego (mamy tu fabułę, postaci czy symbole), jak i cechy pisarstwa filozoficznego czy politycznego. Może być również ważną formą społecznej krytyki lub polemiki. Niezmiernie istotnym wymiarem utopii jako gatunku jest też jej wydźwięk pedagogiczny i edukacyjny, chociaż akurat ten aspekt jest relatywnie rzadko podejmowany w literaturze krytycznej" (Nicieja, 2017: 84). I w tym kontekście nastąpi dalsza analiza utopijności versus realności założeń Jana Amosa Komeńskiego, odnoszących się do pedagogiki i szeroko rozumianej edukacji oraz problemów społecznych.

\section{Utopia versus realizm w założeniach pedagogicznych i społecznych Komeńskiego}

Refleksja nad utopijnością założeń J.A. Komeńskiego jest tyleż samo złożona, co samo pojęcie utopii. Jego wizja kształcenia i wychowania jest krytyką panujących w jego czasie stosunków społecznych, którym próbuje się przeciwstawiać. Konstruuje w swym wyrazie eudajmonistyczny obraz świata, mogący stanowić panaceum na wszelkie jego bolączki, by zaradzić problemom społecznym. Postulaty edukacyjne Komeńskiego - jak podkreśla Barbara Sitarska - „określają całkowicie nową i radykalnie odmienioną, w stosunku do epoki, jego filozofię wychowania i kształcenia. Akceptuje ona prawo każdej jednostki ludzkiej do rozwoju poprzez kreację edukacyjną. Humanistyczna wartość tego wyjątkowego i uniwersalnego postulatu polega na szczególnej misji człowieka mądrego i etycznego w nowym świecie. A wiedza i wychowanie uczynią świat lepszym i pełnym ludzkiego szczęścia” (Sitarska, 2015: 32).

Jak wydaje się dzisiaj, postulat ten nie stracił na wartości i jest w dalszym ciągu jednym ze sztandarowych haseł w edukacji, tyle tylko, że nie zawsze idzie on w parze z edukacyjną rzeczywistością. Współcześnie, tak jak i w epoce Komeńskiego, świat jest pełen różnic i sprzeczności, a edukacyjne nierówności są przedmiotem badań $\mathrm{w}$ socjologii edukacji, $\mathrm{w}$ pedagogice, w tym pedagogice społecznej czy pedagogice specjalnej (chodzi np. o nierówności społeczne czy o deficyty rozwojowe utrudniające dostęp do edukacji). Mają one także różne oblicza społeczne, na które wskazuje w interdyscyplinarnej pracy zbiorowej Jarosław Klebaniuk (2007). Wymienia w niej ekonomiczne, społeczno-polityczne, kulturowe, psychospołeczne, kliniczne oblicza nierówności. Jak pisze sam redaktor pracy „nierówności społeczne, choć zazwyczaj wynikają z hierarchicznej organizacji społeczeństwa, wertykalnego układu relacji międzyludzkich i zróżnicowanego dostępu do władzy i zaso- 
bów materialnych, mają przecież różne wymiary, aspekty i oblicza (...)" (Klebaniuk, 2007: 13). Czym różni się współczesny świat od siedemnastowiecznej Europy Komeńskiego? Czy jego wizja kształcenia i wychowania nie wyrosła ze społecznych nierówności, których był obserwatorem? Już wcześniej Thomas Morus w swojej Utopii konstruował wizję świata, u podstaw której leżały radykalne rozwiązania społeczno-polityczne. Jak podkreśla wspomniany już Stankomir Nicieja, diagnoza świata u Morusa jest aktualna, bowiem „większość patologii rodzi się przez ogromne nierówności społeczne, wynikające z chciwości i pazerności elit, gdyż tak naprawdę tylko elity mogą sobie na chciwość i pazerność pozwolić. To właśnie chęć poskromienia czy wręcz całkowitego wyeliminowania ludzkiej chciwości leży u podstaw niemal wszystkich radykalnych rozwiązań społecznych i politycznych proponowanych przez wielkiego Anglika" (Nicieja, 2017: 87). Czyż nie podobną diagnozę konstruuje Komeński?

W opracowaniu Labirynt świata i raj serca (1914), stanowiącym wprawdzie przykład literatury religijnej, wskazuje on na nierówności społeczne i podobnie jak Morus, piętnuje społeczne różnice wyzwalane przez chytrość i niesprawiedliwość, co w rezultacie prowadzi do nędzy wykorzystanych i piętnowanych. Niweczy tym obraz szczęśliwego świata i jego harmonii oraz społeczny ład, co staje się utopijną wizją sprawiedliwego świata. Utwór kończący się wołaniem do Boga jest jednocześnie krytycznym tłem stosunków społecznych, nierówności, które w obliczu przemijalności życia stają się nicością, a pochwała Boga i łączność z nim jedynym sensem egzystencji. Poza teologicznym kontekstem wspomnianego utworu jest on doskonałą metaforą całej społecznej struktury (stanów społecznych, zawodów, społecznej hierarchii, będącej źródłem ekonomicznych i społecznych nierówności). Wskazuje zauważalne przez Komeńskiego dysproporcje społeczne, które mimo mistycznej oprawy wyraźnie obrazują stan stosunków społecznych i ukazują świat doczesny, wypełniony cierpieniem, pracą, niesprawiedliwością i wyzyskiem.

Egalitaryzm głoszony przez Komeńskiego jako opór wobec społecznej hierarchizacji i przemocy wobec słabszych był utopią wówczas i jest dzisiaj. Konstruuje on dla niej zbawczy program, jakim staje się pansofia, będąca systemem wiedzy i praktyki wobec zła i nierówności. Z języka greckiego oznacza wszechwiedzę, wszechmądrość, jest „wiedzą o wszystkim, co jest, o sposobach istnienia wszystkich rzeczy oraz o ich przeznaczeniu i pożytku” (za: Sztobryn, 2016: 26). Pansofia odrzuca wszelką przemoc i nietolerancję, $\mathrm{w}$ tym też religijną, prowadząc ku odnowieniu społeczeństw (Bieńkowski, 2000: 88-89). Wadliwość porządku społecznego wymusza według Komeń- 
skiego radykalną przebudowę kształcenia i wychowania, bo tylko ono staje się jedyną szansą na poprawę egzystencji i mądrość. Komeński „wierzył - jak podkreśla Barbara Sitarska - że wychowanie i nauczanie według właściwej metody usunie niezgody i spory panujące na świecie i pozwoli osiągnąć im poziom dotychczas nieznany" (2015: 32). Powszechność edukacji jest zatem kluczem do szeroko rozumianego rozwoju, co sprawia, że w pismach Komeńskiego pojawia się krytyka ówczesnej mu szkoły, jej metod i roli. Podejmuje on w pewien sposób jej rekonstrukcję, kreśli wizję, która pozwoliłaby spełniać oczekiwania i zapotrzebowanie społeczne. Heliodor Muszyński podjął się nakreślenia funkcji szkoły według Komeńskiego, którego twórczość pedagogiczną zwykle sprowadza się do analiz w zakresie dydaktyki (2015). Według Muszyńskiego Komeński nadał szkole funkcję społeczną, potraktował ją jako środowisko społeczne, a zatem miejsce, gdzie nie zachodzi tylko recepcja wiedzy, często przekazywana w sposób instrumentalny. Szkoła jest miejscem, gdzie zachodzą interakcje społeczne, gdzie tworzą się zręby modeli społecznego funkcjonowania i życia w świecie. Komeński według Muszyńskiego „określa szkołę jako «zespół nauczających i uczących się», stanowiącą zarazem małą «zorganizowaną społeczność», której «spójnia» zapewniona jest przez przepisy regulujące wspólne życie i działanie podporządkowane realizacji celów kształcenia i wychowania" (Muszyński, 2015: 108).

W konkluzji autor widzi u Komeńskiego szkołę, „(...) której zadaniem jest wprowadzić uczniów w świat przeżyć, doznań i doświadczeń, po to, by przygotować ich do użytecznego społecznie, a zarazem bogobojnego życia, jak też do osiągania w tym życiu - tutaj, na Ziemi - osobistego szczęścia" (Muszyński, 2015: 108). Mimo eudajmonistycznego wydźwięku, a zarazem pewnego praktycyzmu i procesu socjalizacji Komeński wyznacza szkole, jako instytucji edukacyjnej - powiedzielibyśmy dzisiaj - zupełnie realne kształty i niezbędne zadania. Tyle tylko, że - jak twierdzi H. Muszyński - „idee szkolnej edukacji, które głosi i próbuje realizować Komeński, pojawią się w historii edukacji szkolnej dopiero po niemal trzech stuleciach - w koncepcjach takich wielkich reformatorów, jak między innymi: Maria Montessori, Georg Kerschensteiner, John Dewey, Celestyn Freinet, Konstanty Uszyński czy Aleksander Neill” (Muszyński, 2015: 112). Co więc różni wizję szkoły u Komeńskiego od koncepcji Nowego Wychowania, jego amerykańskich i europejskich przedstawicieli? Niewątpliwie wszystkie z nich były dążeniem do stworzenia nowego systemu edukacji, gdyż tradycyjny system nie odpowiadał na nowe realia społeczne. Były one najzwyczajniej progresywną koncepcją wychowania i antycypacją społecznych potrzeb. Jeśli takie koncepcje i wizje naznaczone nową perspektywą nie zyskują uznania w swoim czasie historycznym 
z różnych, czasem bardzo złożonych przyczyn, to czy są one utopią, czy raczej oznaczają społeczną i kulturową stagnację, niechęć do zmian, oportunizm i defensywność? Wydaje się, że pewne założenia Komeńskiego, szczególnie te dotyczące jego pedagogicznych wizji, są prekursorską wizją szkoły, społecznego charakteru edukacji, autonomii jednostki, wyzwolonej ze społecznych i ideologicznych gorsetów, które wcześniej lub później stają się faktem. Czasy, w których przyszło żyć Komeńskiemu, nie należały do spokojnych. Marzenia o nowym ładzie społecznym pobudzały do tworzenia koncepcji człowieka będącego współtwórcą świata, w którym egzystował. Człowiek wolny kreuje wolną od ucisków rzeczywistość, a wolność nie jest utopią, lecz stanem rzeczywistym lub pożądanym, szczególnie wtedy, gdy odczuwa się jej ograniczenia.

W wielu opracowaniach poświęconych twórczości Komeńskiego i jego poglądom spotyka się określenie utopia, utopijność, co stawia pod znakiem zapytania realizację jego postulatów. Utopia jest przeciwieństwem realizmu, a kategoria wolności w zależności od panujących warunków może być jednym i drugim. Utrata niepodległości podczas zaborów sprawiała, że myślenie o jej odzyskaniu było niemożliwe, nierealne, utopijne. Według C. Kality człowiek u J.A. Komeńskiego jest „wolnym użytkownikiem świata” (Kalita, 2016), a „korzystanie z wolności zakłada konieczność uzyskiwania lepszych rezultatów, czy większego dobra, co w dużym stopniu wynika z fundamentalnego charakteru wolności w odniesieniu do moralności. To dzięki wolności istnieje możliwość doskonalenia i samodoskonalenia" (Kalita 2016: 66). Pamiętajmy jednak, że wolność człowieka u Komeńskiego realizuje się w granicach rozumu i porządku moralnego nadanego przez Boga. Pojawiający się u Komeńskiego ład aksjonormatywny jest regulatorem dopuszczalnych granic ludzkiego działania (Komeński, 1964: 84). Owo działanie dokonuje się przez odpowiednią edukację, w której dostrzega on konieczność kształcenia ducha i wychowania moralnego. Jak pisze w swojej Wielkiej Dydaktyce: „Trzeba przeto jak najbardziej dbać o to, aby zasady owej sztuki prawdziwego wszczepiania moralności i prawdziwej bogobojności dokładnie ustalono i wprowadzono do szkół, dzięki czemu szkoły stałyby się w pełni tym, czym się je nazywa, warsztatami ludzkości" (Komeński, 1956: 227). W cytowanym fragmencie dopatrzeć się można głębszych treści. Czy Komeński nie sugeruje, że szkoła o tyle staje się „warsztatem ludzkości”, jeśli przyświecają jej jasne, obowiązujące paradygmaty i moralne zasady? Współcześnie trudno ich szukać, w dobie postmodernizmu, lansującego pluralizm ideologii, czasem społecznie szkodliwych już z założenia, rozbuchanej konsumpcji, niszczącej wartościową warstwę ludzkiej natury. Jakże wrażliwy na tę kwestię był Komeński, kiedy w XVII wieku pisał: „Ponieważ życie musi upływać na 
obcowaniu z ludźmi i działaniu, przeto uczyć trzeba dzieci znoszenia spojrzeń ludzkich i wytrwałości we wszelkich szlachetnych pracach, aby nie bały się światła ani nie stały się mizantropami, aby w ospałości nie myślały jedynie o swoim żołądku i nie były bezużytecznym ciężarem ziemi. Cnotę wyrabia się czynami, a nie słowem" (Komeński, 1956: 229). Współczesna szkoła i życie społeczne nie podzielają z pewnością cnót, których brak u Komeńskiego w rozwoju jest wznoszeniem „budynków bez fundamentów” (Komeński, 1956: 227). Powszechny wyścig szczurów, sukcesoryzm i rywalizacja nie służą społecznej integracji i współpracy, lecz prowadzą do osamotnienia, społecznej izolacji, a często dezintegracji osobowości. Komeński pragnął szczęścia człowieka, jego prawidłowego rozwoju i jak pisze wspomniany już Heliodor Muszyński: „Nikt też przed nim nie dysponował tak dojrzałym spojrzeniem na prawidłowości rozwoju człowieka. Twórca naukowej pedagogiki doskonale zdaje sobie sprawę z istoty rozwoju, wyróżnia niezwykle trafnie jego poszczególne fazy i uznaje konieczność ich uwzględnienia w całej organizacji pracy szkoły" (Muszyński, 2015: 123). Inna perspektywa rozwoju człowieka $\mathrm{w}$ tamtym czasie też z pewnością uznawana była za wyimaginowaną koncepcję. Wyrastała poza akceptowalny poziom wiedzy i świadomości, a Komeński znacznie wyrastał poza obowiązujące w jego epoce paradygmaty.

Idea szkoły Komeńskiego jest warsztatem ludzkości, a nawet precyzując - jej kuźnią, gdzie kształtuje się charaktery, postawy i cnoty. Należą do nich roztropność, będąca „przyznawaniem rzeczom ich właściwej wartości” i przeciwieństwem „przewrotności sądów”; wstrzemięźliwość rozumiana jako „przestrzeganie jej przy pobieraniu pokarmu i napoju, w śnie i czuwaniu, w pracach i zabawach, w mowie i milczeniu, przez cały czas trwania nauki”; męstwo będące umiejętnością „w pokonywaniu samych siebie, w przezwyciężaniu chęci rozbiegania się, bawienia się (...), w opanowywaniu zniecierpliwienia, przekory, gniewu, a także pełna godności postawa i wytrwałość w pracy"; sprawiedliwość przejawiająca się w szacunku dla innych, unikaniu „kłamstwa i podstępów” (Komeński, 1956: 227-229). Koncepcja wychowania Komeńskiego, niezwykle bogata w różne jej aspekty i odniesienia do ludzkiej natury i świata społecznego, jakże nie przystaje do współczesnego wychowania, traktowanego w wielu koncepcjach wychowawczych jako urabianie, stresowanie, co podkreślają szczególnie antypedagodzy (Miller, 2007; Schoenebeck, 2007). Współczesne wychowanie bezstresowe stało się powszechnie obowiązującym modelem, w którym nie ma miejsca na odpowiedzialność, szacunek dla innych. Mocno zliberalizowane współczesne koncepcje wychowania usuwają w cień tradycjonalizm jako przykład archaizmu, będący raczej synonimem zacofania niż rozwoju i obowiązujących trendów. Jak określił to cytowany już Andrzej Dróżdż „w świecie zamazanych wartości i wątpliwych 
autorytetów korzystanie z rozumu przestaje być warunkiem kulturowej adaptacji, co więcej - może stać się czymś anachronicznym i wstydliwym" (2000: 5). Masowa kultura, a zatem i życie społeczne wypierają obowiązujące wcześniej wzorce zachowań i cenione przymioty, zastępując je tanią, łatwą, lekką i przyziemną egzystencją, najlepiej bez cech indywidualizmu i oryginalności. Te również nie są już w cenie. Dyskwalifikują i ośmieszają w masowym, medialnym, propagandowym przekazie. Im bardziej różnimy się od siebie, tym gorzej dla społecznego współistnienia, a przecież wielość i różnorodność świata gwarantuje jego bogactwo.

Oceniamy Komeńskiego, próbujemy interpretować jego wizję świata, osądzamy, czy jest utopią, czy realnym programem, który mógłby być realizowany współcześnie. A czy ktokolwiek z nas zastanowił się nad tym, jak oceniłby współczesny świat Komeński? Sądząc z jego ponadczasowych założeń pedagogicznych i społecznych, w których stworzył koncepcję szkoły, a w niej wychowania i nauczania, wolności i niezależności myślenia, budowania systemu wiedzy $\mathrm{w}$ połączeniu z prawami naturalnymi, podmiotowości i wartości każdego człowieka, połączenia wiedzy i życia z boską ontologią, współczesny świat, mimo swoje technologicznej i naukowej doskonałości, nie jawiłby się mu do końca bezpieczną przestrzenią. Jest to wynikiem wielu złożonych uwarunkowań, w tym politycznych, ekonomicznych, kulturowych czy ekologicznych. Harmonijność - o czym Komeński wielokrotne wspomina, w tym także w pansofii - jest warunkiem niczym nie zakłócanego rozwoju. Tymczasem współcześnie trudno jest postrzegać świat w kategoriach harmonijnego rozwoju, zważywszy na obecność konfliktów, zagrożeń ekologicznych i wielu innych procesów i zdarzeń, mimo haseł zrównoważonego rozwoju. Jak pisze Tadeusz Bieńkowski, pansofia „miała być drogą do odnowienia społeczeństw, poprawy spraw ludzkich, a więc usunięcia ignorancji, fanatyzmu, przemocy" (Bieńkowski, 1998: 89). Przywołując cechy takie, jak: wolność, tolerancja i zgodne współżycie między ludźmi, autor odnosi się do pansofii Komeńskiego, w której „tylko człowiek odpowiednio (tj. pansoficznie) wykształcony i wychowany zdoła zrozumieć i zaakceptować te wartości" (Bieńkowski, 1998: 89). Inny autor uznaje - analizując założenia pansofii i poglądów Komeńskiego - że „pansoficznie kształceni ludzie mieli w jego koncepcji poznać prawdę, zdobyć mądrość i dzięki harmonii osiągnąć prawdziwe szczęście. Pansoficzne kształcenie miało dać w efekcie świat pełen mędrców, świat pokoju i ładu" (Sztobryn, 2016: 30). Obecną edukację trudno jest zestawić i porównać z nauczaniem w epoce Komeńskiego. Jego koncepcja wychowania obejmuje całe życie człowieka, a Komeński „swój program doskonalenia ludzi i świata postrzega (...) w wielokierunkowych działaniach, zorientowanych na uniwersalną konstrukcję edukacji bez granic, do ostatniej 
chwili życia człowieka" (Sitarska, 2015: 31). Wspomniana autorka przywołuje jedną z ważniejszych idei Komeńskiego w pedagogice, że „kształcić należy nie tylko chłopców/mężczyzn, ale też dziewczyny/kobiety; nie tylko młodzież w pełni sprawną, ale i niepełnosprawną (...)", co dzisiaj w ramach pedagogiki inkluzyjnej realizuje się w edukacji publicznej (Sitarska 2018: 231). Istotą pedagogicznych poglądów Komeńskiego jest ich ścisła zależność z życiem społecznym, co oznacza rozumienie przez niego edukacji przez pryzmat procesów socjalizacyjnych, wdrażania do życia społecznego i przygotowania do pełnoprawnego i rozwijającego w nim uczestnictwa. Nie wydaje się nam to dzisiaj niczym szczególnym, ale w innych warunkach społecznych takie myślenie najpewniej wyrastało mentalnie ponad ówczesne standardy. 0 poglądach Komeńskiego, jego wizji szkoły i transgresyjnej wizji człowieka (Sztobryn, 2016: 30) napisano wiele, a wydźwięk tych publikacji i opracowań jest z pewnością - mimo oparcia się na źródłach - naznaczony subiektywizmem każdego z autorów. Jak jednak podkreśla Sławomir Sztobryn „poszukując antecedencji współczesności, nie możemy nakładać na przeszłość własnych matryc wyobrażeń, definicji, własnego kontekstu. (...) Historia płynie wieloma torami. To, co rejestrujemy na powierzchni, nie musi być identyczne z tym, co jest ukryte głębiej, co trzeba sobie introspekcyjnie uświadomić" (Sztobryn, 2020: 25).

\section{Komeński - utopia - realizm. Próba konstatacji}

We wcześniejszych rozważaniach o utopii i jej związkach z pedagogiką Andrzej Dróżdż zauważa paradoks: pedagogika powinna być wolna od utopii, ale organizując przestrzeń edukacyjną nigdy nie uwolni się od pierwiastka utopijnego. $\mathrm{W}$ pedagogice, zarówno w teorii, jak i w praktyce zawsze jest coś w fazie oczekiwania, planowania (Dróżdż, 2000: 7). Jeśli utopia jest metafizyczną tęsknotą człowieka za spełnieniem, poszukiwaniem prawdy i doskonałości, to wykluczenie jej z praktyki pedagogicznej jest jednocześnie odrzuceniem uniwersalnych prawd i nadziei, sprowadzeniem człowieka do homo faber czy homo oeconomicus (Głażewski, 2017: 39-40). Nie o takiej wizji człowieka mówimy w analizach tekstów Komeńskiego. Wizje te są o wiele głębsze w swych przekazach i bardziej uniwersalne, co pozwala uznać je za bardzo realistyczne i nieprzemijające. Komeński z pewnością kreślił rysy wymarzonej szkoły, pożądanych zmian społecznych, co w tamtym czasie nie znajdowało uznania i znacznie odbiegało od realiów. Rozwinięta u Komeńskiego idea podmiotowości w nauczaniu i wychowaniu, kiedy jeszcze daleko w przyszłości znajdowała się koncepcja Nowego Wychowania, znajomość zasad rozwojowych, egalitaryzm w kształceniu i opracowanie metod nauczania opartych 
na indywidualnej aktywności dziecka (Komeński, 1956), pozwala przyjąć utopijne wówczas wizje za spełniające się rozwiązania w późniejszych epokach. I takich przykładów obok Komeńskiego jest wiele, choćby szkoła Aleksandra S. Neilla czy wychowawcza wizja Janusza Korczaka. Relacja utopii z pedagogiką staje się z jednej strony planem i koncepcją, z drugiej zaś znajduje w dogodnym czasie i warunkach miejsce i sposób ich urzeczywistnienia. Można zatem przyjąć, że pedagogiczne utopie stają się realne, a realne założenia w praktyce edukacyjnej mogą stać się niekiedy utopią. Wyjątkowość i ponadczasowość koncepcji i poglądów Komeńskiego - z czego wynika też kategoria utopii stosowana w licznych interdyscyplinarnych analizach naukowych - stawiała go zawsze w szeregu myślicieli wykraczających poza dopuszczalne ramy i sposoby recepcji świata. Sądzę, że komeniologia jest przykładem ewoluowania teorii i pism Komeńskiego, zakreślając coraz szersze horyzonty jego uniwersalizmu, realnych wartości i zastosowań. Nie sposób ich wszystkich wymienić i wskazać. Podjęta w niniejszym artykule próba przedstawienia poglądów pedagogicznych i społecznych Jana Amosa Komeńskiego z uwzględnieniem kategorii utopii i realizmu staje się możliwa tylko w łączności ze współczesnością, która często w sposób niezauważalny sięga do przeszłości.

\section{Bibliografia}

Bieńkowski Tadeusz, Jan Amos Komeński o nauczaniu i wychowaniu, wyd. 2, Pułtusk 2000.

Bieńkowski Tadeusz, Jan Amos Komeński o nauczaniu i wychowaniu, Pułtusk 1998.

Chojnacka Barbara, Ciarcińska Katarzyna, Edukacja jako gwarancja szczęścia - od Utopii do Summerhill. Perspektywa filozoficzno-pedagogiczna, w: R. Włodarczyk (red.), Utopia a edukacja. Pedagogiczne konteksty społecznych wyobrażeń, t. II, Wrocław 2017, s. 95-108.

Dobrowolska B., Pansofia Komeńskiego współcześnie: archaizm czy transgresyjna koncepcja człowieka $w$ ujęciu uniwersalnym. Społeczne, edukacyjne i kulturowe wymiary, B. Sitarska (red.), Pansofia Jana Amosa Komeńskiego w interpretacjach $i$ reinterpretacjach polskich $i$ europejskich komeniologów, „Siedleckie Zeszyty Komeniologiczne, seria pedagogika", t. VII, Siedlce 2020, s. 107-130.

Dróżdż Andrzej, Mity i utopie pedagogiczne, Kraków 2000.

Ferenz Krystyna, Między wizjq a utopią. Rola edukacji, w: R. Włodarczyk (red.), Utopia a edukacja. Pedagogiczne konteksty społecznych wyobrażeń, t. II, Wrocław 2017, s. 17-27.

Głażewski Michał, Terra Utopia. Głosy i konteksty pedagogiczne utopii, w: R. Włodarczyk (red.), Utopia a edukacja. Pedagogiczne konteksty społecznych wyobrażeń, t. II, Wrocław 2017, s. 28-48.

https://encyklopedia.pwn.pl/haslo/utopia;3991950.html, dostęp: 29.06.2021. 
Kalita Cezary, Jana Amosa Komeńskiego człowiek jako „wolny użytkownik świata”, B. Sitarska (red.), Jan Amos Komeński - współczesne interpretacje i reinterpretacje jego twórczości, „Siedleckie Zeszyty Komeniologiczne, seria pedagogika”, t. III, Siedlce 2016, s. 63-70.

Klebaniuk Jarosław, (red.), Oblicza nierówności społecznych. Studia interdyscyplinarne, Wrocław-Warszawa 2007.

Komeński Jan Amos, Labirynt świata i raj serca, opr. ks. Jan Pindór, Cieszyn 1914.

Komeński Jan Amos, Preludium do wszechwiedzy, w: J.A. Komeński, Pisma wybrane, Wrocław-Warszawa-Kraków 1964, s. 84.

Komeński Jan Amos, Wielka dydaktyka, Wrocław 1956.

Miller Alice, Dramat udanego dziecka. W poszukiwaniu siebie, Poznań 2007.

More Thomas, Utopia, tł. Kazimierz Abgarowicz, Warszawa 2001.

Muszyński Heliodor, Komeńskiego koncepcja szkoły, B. Sitarska (red.), Jan Amos Komeński - jego pedagogika i filozofia, „Siedleckie Zeszyty Komeniologiczne, seria pedagogika", t. II, Siedlce 2015, s. 101-128.

Nęcka Edward, Psychologia twórczości, Gdańsk 2001.

Nicieja Stankomir, Współczesne spojrzenie na edukacyjne i pedagogiczne motywy $w$ dziele Tomasza Morusa Utopia, w: R. Włodarczyk (red.), Utopia a edukacja. Pedagogiczne konteksty społecznych wyobrażeń, t. II, Wrocław 2017, s. 84-94.

Schoenebeck Hubertus, Antypedagogika. Być i wspierać zamiast wychowywać, Łódź 2007.

Sitarska Barbara, Jan Amos Komeński w trzecim tysiqcleciu. Odczytania - kontynuacje krytyka, B. Sitarska (red.), Jan Amos Komeński w epoce współczesności. Odczytania - kontynuacje - krytyka, „Siedleckie Zeszyty Komeniologiczne, seria pedagogika", t. V, Siedlce 2018, s. 211-250.

Sitarska Barbara, O Janie Amosie Komeńskim i poczq̨tkach komeniologii, B. Sitarska (red.), Jan Amos Komeński. Jego pedagogika i filozofia, „Siedleckie Zeszyty Komeniologiczne, seria pedagogika", t. II, Siedlce 2015, s. 23-44.

Suchodolski Bogdan, Komeński, Warszawa 1979.

Sztobryn Sławomir, W poszukiwaniu pansofii Komeńskiego w badaniach polskich komeniologów, B. Sitarska (red.), Pansofia Jana Amosa Komeńskiego w interpretacjach i reinterpretacjach polskich i europejskich komeniologów, „Siedleckie Zeszyty Komeniologiczne, seria pedagogika”, t. VII, Siedlce 2020, s. 23-36.

Sztobryn Sławomir, Wprowadzenie do pansoficznych podstaw pedagogiki Jana Amosa Komeńskiego, B. Sitarska (red.), Jan Amos Komeński - współczesne interpretacje i reinterpretacje jego twórczości, „Siedleckie Zeszyty Komeniologiczne, seria pedagogika", t. III, Siedlce 2016, s. 25-33.

Śliwerski Bogusław, Utopia edukacyjnych utopii, w: R. Włodarczyk (red.), Utopia a edukacja. Pedagogiczne konteksty społecznych wyobrażeń, t. II, Wrocław 2017, s. 11-16.

Utopiści XVI i XVII wieku o wychowaniu i szkole, wstęp, wybór i oprac. W. Voise, Wrocław-Kraków-Gdańsk 1972. 